\title{
Fruit growth characteristics of four pomegranate cultivars from northern Oman
}

\author{
Rashid AL-YAHYAI ${ }^{1 *}$, Fahad AL-SAID ${ }^{1}$, Linus OPARA ${ }^{2}$
}

${ }^{1}$ Dep. Crop Sci., Coll. Agric. Marine Sci., Sultan Qaboos Univ., PO Box 34, Al-Khoud 123, Oman alyahyai@squ.edu.om

2 Dep. Horticultural Sci., Fac. AgriSci., Univ. Stellenbosch., PB X1, Stellenbosch 7602, South Africa

${ }^{*}$ Correspondence and reprints

Received 22 October 2008 Accepted 3 February 2009

Fruits, 2009, vol. 64, p. 335-341 (C) 2009 Cirad/EDP Sciences All rights reserved DOI: 10.1051/fruits/2009029 www.fruits-journal.org

RESUMEN ESPAÑOL, p. 341

\section{Fruit growth characteristics of four pomegranate cultivars from northern Oman.}

Abstract - Introduction. Pomegranate (Punica granatum L.) is the main and most valuable fruit crop of the northern mountainous region of Oman. Pomegranates are cultivated utilizing traditional farming methods including the determination of harvest dates, harvesting and postharvest handling. Materials and methods. Fruit of four native pomegranate cultivars ['Hamedh', 'Malasi', 'Helow' and 'Qusum', literally translated as sour, smooth, sweet and hardseeded, respectively] were tagged and monitored for 3 months up to commercial harvest. Fruit length (L) and diameter (D) were measured at weekly intervals starting from $66 \mathrm{~d}$ after full bloom until harvest (136 d after full bloom). Results and discussion. During the time course of fruit growth and development, significant changes occurred in fruit shape assessed by the [fruit length / fruit diameter] ratio in two cultivars ('Malasi' and 'Hamedh'), but not in the 'Helow' and 'Qusum' cultivars, which also had larger fruit size at harvest. The lack of obvious changes in fruit shape during growth and development of 'Qusum' and 'Helow' pomegranate cultivars indicates that the attainment of characteristic fruit shape may not be a good indicator of their maturity for harvest management. Thus, fruit harvesting based solely on size and shape is not sufficient and other physico-chemical fruit attributes should be taken into account when assessing readiness to harvest to ensure optimum income returns to growers.

Oman / Punica granatum / fruits / growth rate / developmental stages / harvesting / development indicators

\section{Caractéristiques de la croissance du fruit de quatre cultivars de grenadiers au nord d'Oman.}

Résumé - Introduction. Le grenadier (Punica granatum L.) est le principal et le plus valable arbre fruitier de la région montagneuse du nord d'Oman. Les grenadiers y sont cultivés selon des méthodes agricoles traditionnelles, dont la détermination des dates de récolte, et les techniques de récolte et de manutention après récolte. Matériel et méthodes. Les fruits de quatre cultivars de grenade indigène ['Hamedh', 'Malasi', 'Helow', and 'Qusum', littéralement traduit comme " aigre ", " lisse ", " doux " et " à graines dures "] ont été étiquetés et suivis pendant 3 mois, jusqu'à la récolte commerciale. La longueur du fruit et son diamètre ont été mesurés chaque semaine, de $66 \mathrm{j}$ après la pleine floraison jusqu'à la récolte (136 j après la pleine floraison). Résultats et discussion. Pendant la période de croissance et développement du fruit, des changements cruciaux se sont produits pour la forme de fruit, évaluée par le rapport [longueur de fruit / diamètre de fruit], de deux cultivars ('Malasi' et 'Hamedh') mais il n'y a pas eu de changement de forme pour les cultivars 'Qusum' et 'Helow' qui ont présenté tous deux une plus grande taille du fruit à la récolte. Le manque de changements évidents de forme du fruit pendant la croissance et le développement des grenades 'Helow' et 'Qusum' indique que l'acquisition d'une forme caractéristique du fruit peut ne pas être un bon indicateur de maturité pour la gestion de la récolte. Ainsi, la taille et la forme des fruits ne peuvent être les seuls caractères à prendre en compte pour décider de la date de récolte et d'autres caractéristiques physico-chimiques du fruit devraient être considérées pour évaluer le point de récolte permettant d'assurer un revenu optimal aux cultivateurs.

Oman / Punica granatum / fruits / taux de croissance / stade de développement / récolte / indicateur de développement 


\section{Introduction}

Pomegranate (Punica granatum L. family: Punicaceae) is a subtropical fruit crop that is native to Iran and is currently cultivated throughout the world for its highly nutritious fruit arils. This species has been cultivated for centuries in many parts of the world such as Western Asia, Africa and Southern Europe [1]

Due to its high-altitude mountains and semi-arid climate, the Al Jabal al Akhdar area of northern Oman $\left(23^{\circ} 04^{\prime} \mathrm{N}\right.$ long., 57³8' E lat., and approximately $3000 \mathrm{~m}$ alt.), in the mountains of Al Hajar, is ideal for the cultivation of pomegranates. The minimum temperature during the winter months (Dec. Feb.) reaches below $0{ }^{\circ} \mathrm{C}$, which allows the cultivation of various low-chill deciduous fruit crops. Vegetative bud break and bloom of pomegranates in these mountains begin at the end of March through April. During the fruit development phase, the temperature continues to rise, reaching an average of $35^{\circ} \mathrm{C}$ during the peak summer months (June-August). These climatic conditions are considered ideal for the cultivation of high quality pomegranates similar to major producing countries such as Turkey [2]. Several local cultivars are grown throughout the range of the Hajar mountains in northern Oman but the sweet type 'Helow' occupies the largest cultivated area. Other cultivars are grown to a much lesser extent due to undesirable characteristics such as hard seed (cv. 'Qusum'), or smaller size and smoother skin that is more susceptible to bruising (cv. 'Malasi'). Other cultivars are left to grow in the wild due to their highly acidic taste and small fruit size, often referred to as 'Hamedh', meaning "sour" [3]. Despite the undesirable eating quality or marketing attributes of some of these cultivars, they are grown commercially for alternative uses such as for juices, traditional medicines [4], or fabric dyes.

Fruit sugar and mineral content of pomegranates and other commodities sold in the Omani markets has been investigated by Al-Kindy et al. [5]. Recently, a more thorough study investigated the physico-chemical properties of commonly cultivated pomegranate cultivars in the northern mountainous region of Oman [3]. Results from this study indicated significant differences in the physical and chemical quality of Omani pomegranates.

Harvesting of pomegranates in Oman takes place from July to September but peaks in August. In Oman, pomegranate is mainly consumed fresh and prized for its taste and nutritional value, thus it is three to four times more expensive than imported pomegranates. Proper timing of fruit harvest is essential for maintaining quality produce. Fruit skin and juice color or the [sugar / acid] ratio are the main indicators for harvest in major pomegranate-producing countries [6]. However, harvesting of pomegranates in traditional cultivation in Oman is commonly based on fruit size and attainment of characteristic shape. Local consumers also assess the quality of pomegranates by their size, perhaps due to the high variability in fruit skin color development under the prevailing climate and growing conditions. During marketing, fruits are sorted by their size, and the largest fruits usually fetch the highest price. Fruit growth measurement and analysis is important for yield prediction and development of optimal maturity indices in fruit crops such as apples [7-9]. Despite the long history of pomegranate cultivation and utilization in the Al Jabal al Akhdar area of Oman [4], there is no reported study on the fruit growth attributes and maturation of these pomegranate cultivars. The objective of our study, therefore, was to determine the fruit growth characteristics of four pomegranate varieties grown in Oman.

\section{Materials and methods}

\subsection{Plant materials}

Our study was conducted during the pomegranate fruiting season of 2007 in Al Jabal al Akhdar, a mountainous oasis in northern Oman. Four plots of mature pomegranate trees (approximately 50 years old) were used for this study. Each plot had three trees of the four native pomegranate cultivars, namely 'Hamedh', 'Malasi', 'Helow' and 
'Qusum'; literally translated as "sour", "smooth", "sweet" and "hard-seeded", respectively. Trees were grown in traditionally constructed terraces and irrigated weekly. Gebauer et al. provide a description of mountain oasis fruit cultivation in Oman [10].

\subsection{Fruit growth measurements and analysis}

Three replication trees per cultivar were randomly selected for studying fruit growth measurements and analysis. While a slightly larger sample $(\sim 10)$ of fruits per tree has been cited for such studies, we measured only five fruits per replication tree. Indeed, considering the very limited cultivation area, high value (US\$ 5 per fruit compared with US\$ 0.30 per fruit for imported fruits) and rarity of these pomegranates in an arid country such as Oman (figures 1, 2), obtaining a larger number of fruits or trees was not possible. Thus, five fruits per tree were tagged and monitored for 10 weeks up to commercial harvest. Measurements were recorded at weekly intervals starting from $66 \mathrm{~d}$ after full bloom until harvest (136 d after full bloom). Indeed, for the same reasons as those which led to the choice of sampling only five and not ten fruits per tree, and due to cultural opinions about early sale of fruits among pomegranate growers in remote mountains, we also could not obtain fruits for measurements prior to $66 \mathrm{~d}$ after full bloom. The growers auction the fruits only when they are fully mature and ready for harvest (thus with a high price); therefore, auctioning them at an earlier date (i.e., at fruit set) would have violated their traditional beliefs and customs. This may seem strange, but each grower owns only about 3-6 pomegranate trees in an area of $25-60 \mathrm{~m}^{2}$ [3]. There are no large-scale publicly or privately owned pomegranate orchards in the country.

Fruit growth analyses were based on the methods of Opara [7] and Opara and Tadesse $[8,9]$. Lineal fruit growth parameters (length and diameter) were used to quantify cumulative growth. Fruit length and diameter were measured at two opposite longitudinal and equatorial fruit perimeters (excluding the fruit calyx). The following

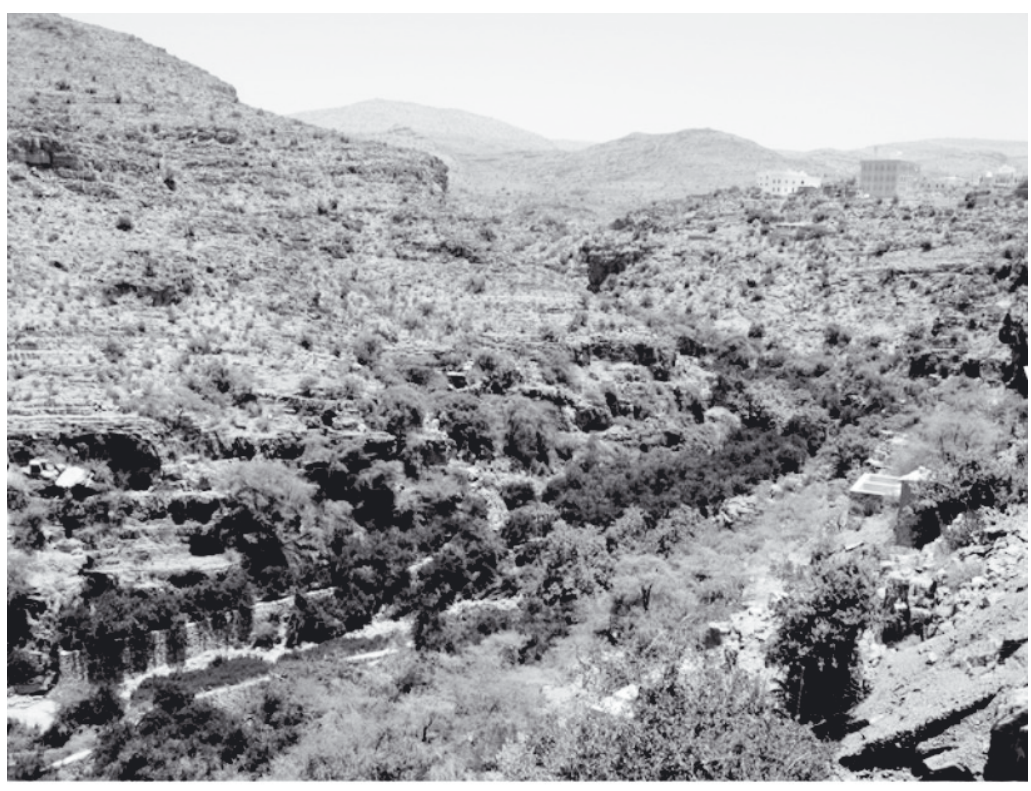

Figure 1.

Pomegranate trees grown among other deciduous fruit trees in a dry valley in $\mathrm{Al}$ Jabal al Akhdar, Oman.

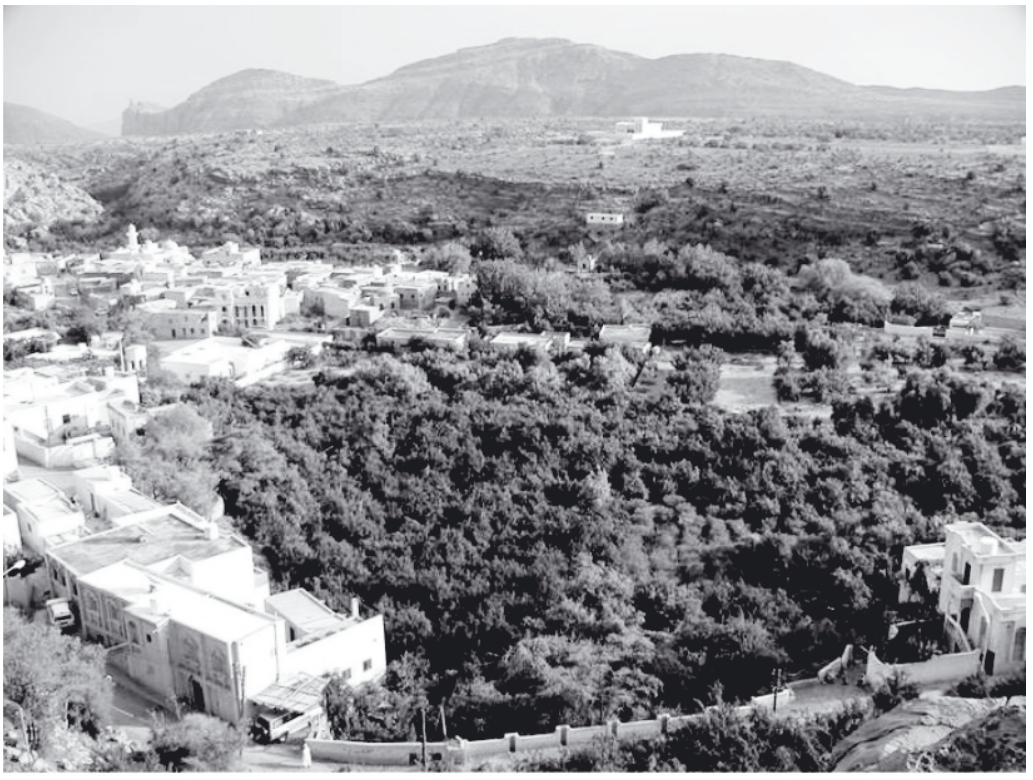

derived indices of fruit growth were calcu- Figure 2.

lated based on the lineal measurements of Aerial view of Saiq, a village in growth: Al Jabal al Akhdar, where high- fruit volume in $\mathrm{cm}^{3}, V=\left[(4 / 3) \times \Pi \times r^{3}\right]$, value pomegranates are where $r$ is the average of the fruit radius of cultivated in small-holder the fruit diameter and length. Fruit volume was calculated by assuming a spherical shape; 
Figure 3.

Fruit diameter and length of four pomegranate cultivars grown in Oman measured from $66 \mathrm{~d}$ after full bloom until harvest $(N=15$, data point average \pm standard error).

\section{Figure 4.}

Fruit spherical volume of four pomegranate cultivars grown in Oman measured from $66 \mathrm{~d}$ after full bloom until harvest $(N=15$, data point average \pm standard error).
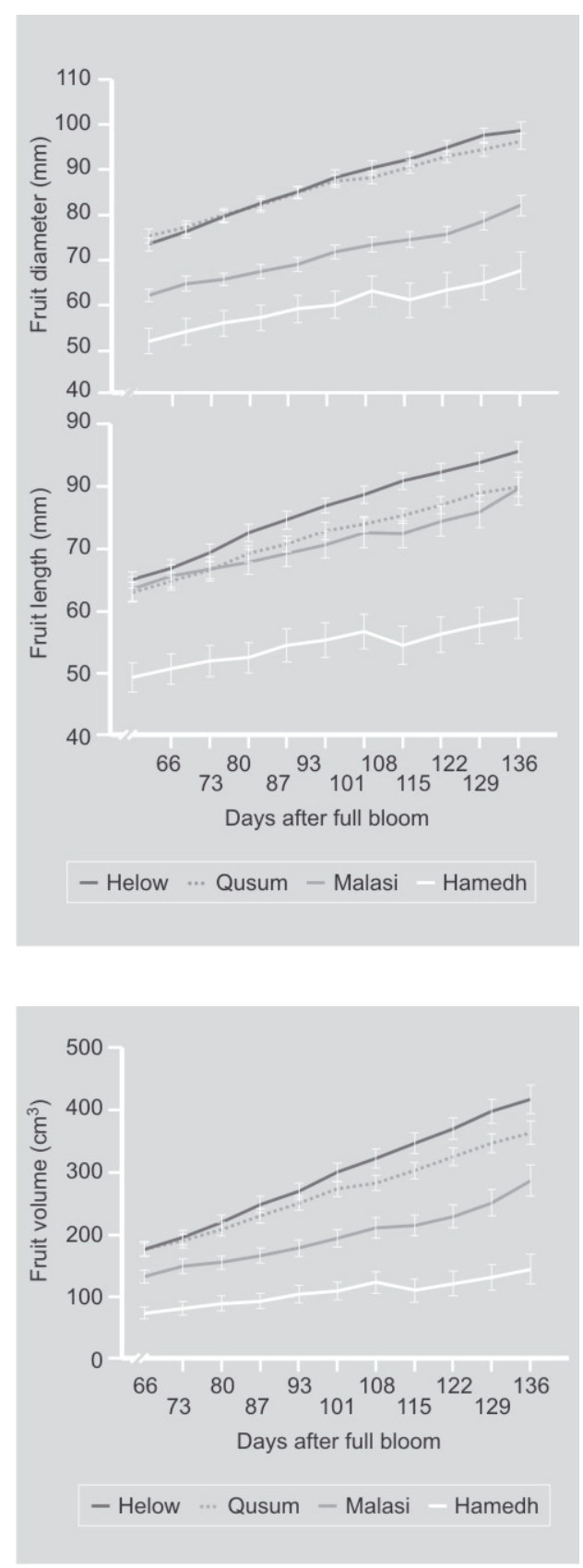

- absolute fruit growth rate in $\mathrm{cm}^{3} \cdot$ week $^{-1}$, $A G R=[\mathrm{d} V / \mathrm{d} t]$, where $t$ is the interval (in days) between measurements;

- relative growth rate in $\mathrm{cm}^{3} \cdot \mathrm{week}^{-1}, R G R=$ $\left[\mathrm{d}\left(\log _{\mathrm{e}} V\right) / \mathrm{d} t\right]$;

- fruit shape index, $S=$ [fruit length / fruit diameter].
Additionally, the means of fruit spherical volume $(V)$ at harvest of the four cultivars were compared using covariance analysis. Initial fruit volumes were used as the covariant and mean differences were determined using Duncan's Multiple Range Test. The GLM Procedure of SAS (SAS Inst., Carey, NC) was used for these calculations.

\section{Results and discussion}

Throughout the growth measurement period [(66 to 136) $\mathrm{d}$ after full bloom], differences in fruit dimensions were measured among some of the local cultivars studied (figure 3). The cultivars 'Qusum' and 'Helow' had the highest fruit diameter, followed by 'Malasi', and the smallest diameter was recorded for the 'Hamedh' cultivar. Fruit length was initially significantly higher for the 'Hamedh', 'Qusum' and 'Malasi' cultivars than for 'Hamedh'. However, when fruit reached maturity, 'Helow' attained the highest fruit length, while 'Hamedh' remained smaller than all other cultivars. A slight decrease in fruit length and diameter of the 'Hamedh' cultivar occurred at $115 \mathrm{~d}$ after full bloom. We speculate that this could be caused by loss of several fruits from the wildly grown 'Hamedh' cultivar and did not influence the final outcome of the results.

To determine the changes in fruit size over time, fruit spherical volume was calculated based on fruit length and diameter measurements. Initially, 'Helow' and 'Qusum' had the largest fruit volume, followed by 'Malasi', while 'Hamedh' had the smallest fruit volume (figure 4). However, covariance analysis showed significant differences in fruit volume among the cultivars, ranging from $417.56 \mathrm{~cm}^{3}$ for 'Helow' to $146.46 \mathrm{~cm}^{3}$ for 'Hamedh' (table I). To illustrate the changes that occurred from the first measurement, cumulative fruit volume was calculated for all cultivars (figure 5). The data showed that, at $87 \mathrm{~d}$ after full bloom, differences in growth rate were observed among the cultivars that initially had the largest fruit volume ('Helow' and 'Qusum') and those with the smallest fruit volume ('Malasi' and 'Hamedh') (figure 5). From $87 \mathrm{~d}$ after full 
bloom, the order of cumulative fruit volume among cultivars was 'Helow' > 'Qusum' > 'Malasi' > 'Hamedh' (figure 5).

Analysis of absolute fruit growth indicated two distinct patterns for all cultivars. The first was from $73 \mathrm{~d}$ after full bloom until $108 \mathrm{~d}$ after full bloom and the second from $115 \mathrm{~d}$ after full bloom until $136 \mathrm{~d}$ after full bloom (figure O). During these two periods, 'Helow' and 'Qusum' had higher fruit growth compared with 'Malasi' and 'Hamedh'. A similar trend was also observed for the relative fruit growth rate (figure 7). Gozlekçi and Kaynak reported a two-phase growth pattern for pomegranate fruit, initially fast, then a second phase with slow fruit growth [11]. This two-phase growth pattern led to the conclusion that pomegranate fruit follows a sigmoidal fruit growth pattern [11-13]. However, our relative fruit growth data did not follow a specific growth trend, perhaps due to late measurements of fruit dimensions (66 d after full bloom), to inherent genetic variability among the cultivars or to the variability in the growing conditions [7].

During pomegranate fruit growth and development, significant changes occurred in fruit shape (sphericity) among the cultivars studied (figure 8). 'Qusum' and 'Helow' cultivars showed little change in shape, while 'Malasi' and 'Hamedh' showed a steady increase in fruit diameter, which resulted in less elongated fruit (declining sphericity) as growth progressed. At harvest, the fruit shape index, the [length / diameter] ratio, was highest for 'Malasi', followed by 'Hamedh' and 'Helow', and lowest for 'Qusum'. The lack of obvious changes in fruit shape during growth and development of the 'Qusum' and 'Helow' pomegranate cultivars indicated that the attainment of characteristic fruit shape may not be a good indicator of their maturity for harvest management. Moreover, changes in fruit shape might coincide with the onset of physical defects that are related to fruit growth stress such as cracking and splitting [14], similar to those occurring to apple fruits $[8,9]$. Thus, measurement of other physico-chemical changes during fruit growth and development (such as sugar, acidity and color) may provide better indicators of readiness to

\section{Table I. \\ Fruit spherical volume at harvest of four pomegranate cultivars grown in Oman.}

$\begin{array}{lc}\text { Cultivar } & \begin{array}{c}\text { Fruit volume at harvest } \\ \left(\mathrm{cm}^{3}\right)\end{array} \\ \text { Hamedh } & 146.46 \mathrm{~d} \\ \text { Malasi } & 289.70 \mathrm{c} \\ \text { Qusum } & 364.56 \mathrm{~b} \\ \text { Helow } & 417.56 \mathrm{a}\end{array}$

Means with different subscripts in the column are significantly different according to Duncan's Multiple Range Test $(N=15, P=<0.0001)$.

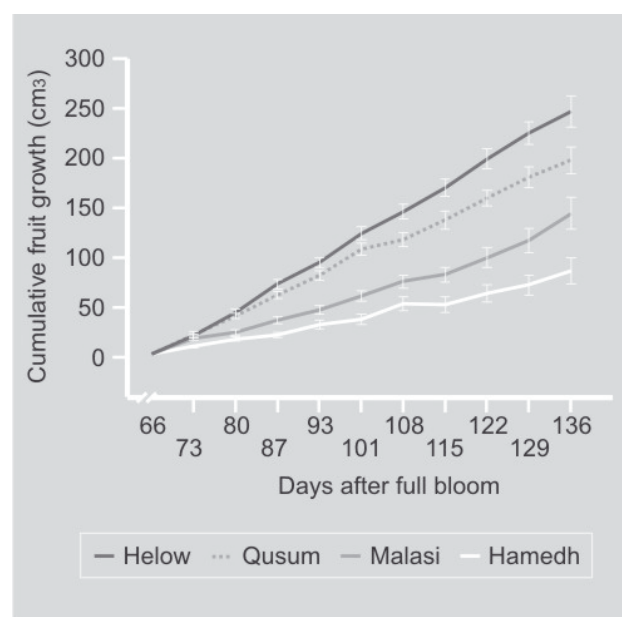

Figure 5.

Cumulative fruit growth of four pomegranate cultivars grown in Oman measured from $66 \mathrm{~d}$ after full bloom until harvest $(N=15$, data point average \pm standard error).

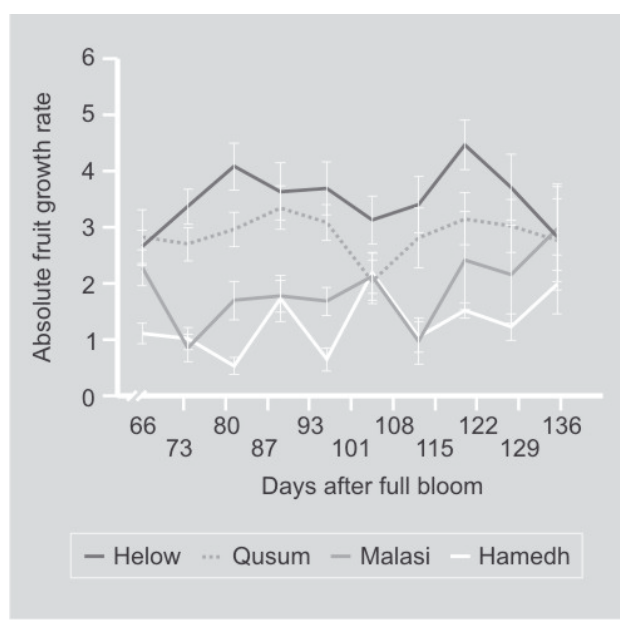

Figure 6.

Absolute fruit growth rate of four pomegranate cultivars grown in Oman measured from $66 \mathrm{~d}$ after full bloom until harvest $(N=15$, data point average \pm standard error) 
Figure 7.

Fruit relative growth rate of four pomegranate cultivars grown in Oman measured from $66 \mathrm{~d}$ after full bloom until harvest $(N=15$ data point average \pm standard error).

\section{Figure 8.}

Fruit shape index (sphericity) of four pomegranate cultivars grown in Oman measured from $66 \mathrm{~d}$ after full bloom until harvest $(N=15$, data point average \pm standard error).
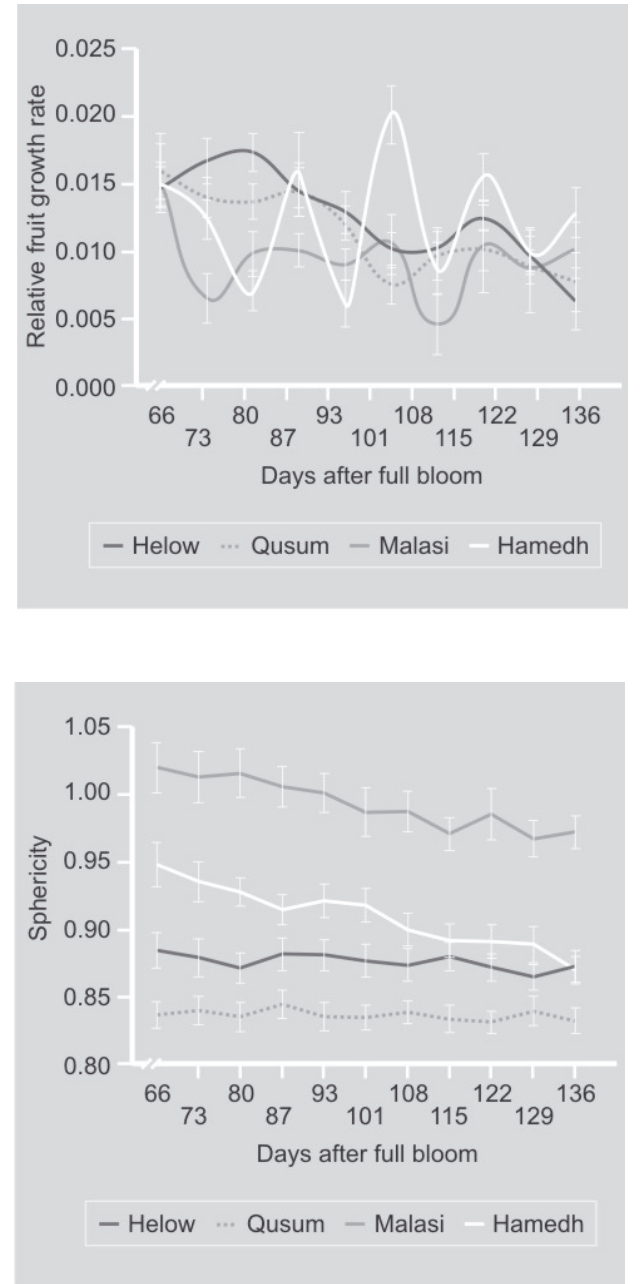

harvest of the pomegranate cultivars studied $[3,4,15]$

\section{Conclusions}

Pomegranate fruit length and diameter continued to grow at various rates among the locally-grown cultivars in the northern mountains of Al Jabal al Akhdar in the Sultanate of Oman. Fruit size at harvest varied significantly among cultivars, with the most commonly grown commercial sweet cultivar 'Helow' having the largest size and the sour-tasting wild cultivar 'Hamedh' having the smallest one. The sigmoidal fruit growth pattern reported for pomegranate was not obvious in this study, perhaps because monitoring and measuring did not start at fruit setting. Nonetheless, two distinct fruit growth rates were observed. The first was from $73 \mathrm{~d}$ after full bloom until $108 \mathrm{~d}$ after full bloom and the second from $115 \mathrm{~d}$ after full bloom until $136 \mathrm{~d}$ after full bloom. Two cultivars showed little change in the fruit shape index, expressed as sphericity, i.e., 'Qusum' and 'Hamedh', while the more rounded 'Malasi' and 'Hamedh' cultivars showed a steady decline in sphericity with fruit development. Our study showed the variable patterns of fruit growth and fruit shape leading to harvest. Because of this variability in fruit shape during the period of commercial harvest, fruit harvesting based solely on size and shape for all cultivars is not sufficient to ensure optimum maturity for fruit utilization and performance during postharvest handling and storage. Other indicators such as the changes in physico-chemical fruit attributes at maturity may be taken into account when assessing readiness to harvest to ensure optimum income returns to growers.

\section{Acknowledgement}

Financial support for this study was provided through His Majesty's Strategic Research Project on "Postharvest Technology of Omani Fresh Produce" (Project No. $\mathrm{SR} / \mathrm{AGR} / \mathrm{BIOR} / 05 / 01)$. The assistance of AlJabal-al-Akhdar Agricultural Development Center of the Ministry of Agriculture is appreciated.

\section{References}

[1] Morton J., Pomegranate, in: Morton J. (Ed.), Fruits of warm climates, J.F. Morton, Miami, Fla, USA, 1987, pp. 352-355.

[2] Özgüven A.I., Yilmaz C., Pomegranate growing in Turkey, Options Méditerr. Sér. A. 42 (2000) 41-48.

[3] Al-Said F., Opara L., Al-Yahyai R., Physicochemical quality attributes of pomegranate cultivars (Punica granatum L.) grown in the Sultanate of Oman, J. Food Eng. 90 (2009) 129-134. 
[4] Opara L.U., Al-Ani M.R., Al-Shuaibi Y., Physico-chemical properties, vitamin C content, and antimicrobial properties of pomegranate fruit (Punica granatum L.), Food Bioprocess Technol. (2008) 315-321.

[5] Al-Kindy S., Abdulnour A., Al-Rasbi M., Determination of sugar and mineral contents in some Omani fruits, SQU J. Sci. Tech. 6 (2001) 39-44.

[6] Crisosto C.H., Mitcham E.J., Kader A.A., Pomegranate: Recommendations for maintaining postharvest quality, Produce Facts, Postharvest Res. Inf. Cent., Univ. Calif., Davis, USA, 2000.

[7] Opara L.U., Fruit growth measurement and analysis, Hortic. Rev. 24 (2000) 373-431.

[8] Opara L.U., Tadesse T., Fruit growth and mineral element accumulation in Pacific Rose apple in relation to orchard management factors and calyx-end splitting, J. Plant Nutr. 23 (2000) 1079-1093.

[9] Opara L.U., Tadesse T., Fruit growth characteristics and chronological development of calyx-end splitting in Pacific Rose apple, J. Am. Pomol. Soc. 54 (2000) 153-159.
[10] Gebauer J., Nagieb M., Bürkert A., Obstbau in einer Bergoase im Norden Omans, Erwerbs-Obstbau 1 (2006) 9-16.

[11] Gozlekçi S., Kaynak L., Physical and chemical changes during development and flowering in pomegranate (Punica granatum L.) cultivar Hicaznar grown in Antalya region, Options Méditerr. Sér. A. 42 (2000) 79-85.

[12] Dhillon W.S., Kumar A., Studies on fruit growth and development in pomegranate, J. Res. Punjab Agric. Univ. 41 (2004) 205-209.

[13] Varasteh F., Arzani K., Zamani Z., Tabatabaei S.Z., Physico-chemical seasonal changes of pomegranate (Punica granatum L.) fruit 'Malas-e-Torsh-e-Saveh' in Iran, Acta Hortic. 769 (2008) 255-258.

[14] Hepaksoy S., Aksoy U., Can H.Z., UI M.A., Determination of relationship between fruit cracking and some physiological responses, leaf characteristics and nutritional status of some pomegranate varieties, Options Méditerr. Sér. A. 42 (2000) 87-92.

[15] Opara L.U., Studman C.J., Banks N.H., Physico-mechanical properties of 'Gala' apples and stem-end splitting as influenced by orchard management practices and harvest date, J. Agric. Eng. Res. 68 (1997) 139-146.

\section{Características de crecimiento del fruto de cuatro cultivares de granado al norte de Omán.}

Resumen - Introducción. El granado (Punica granatum L.) es el principal árbol frutal y el más válido de la región montañosa del norte de Omán. Ahí, los granados se cultivan ahí de acuerdo con métodos agrícolas tradicionales, entre los cuales está la determinación de las fechas de cosecha, así como las técnicas de cosecha y de manutención tras cosecha. Material y métodos. Los frutos de cuatro cultivares de granado indígena ['Hamedh', 'Malasi', 'Helow', y 'Qusum', literalmente traducido como " agrio ", "liso ", "suave " et " de semillas duras "] se etiquetaron y se hizo el seguimiento durante 3 meses, hasta la cosecha comercial. Tanto el largo como el diámetro del fruto se midieron semanalmente desde $66 \mathrm{~d}$ tras la plena floración hasta la cosecha (136 d tras la plena floración). Resultados y discusión. Durante el tiempo de crecimiento y de desarrollo del fruto, se produjeron cambios cruciales en cuanto a la forma del fruto, evaluada por la relación [longitud de fruto / diámetro de fruto], de dos cultivares ('Malasi' y 'Hamedh') pero no hubo cambio de forma para los cultivares de 'Qusum' y 'Helow', los cuales presentaron ambos un tamaño del fruto mayor durante la cosecha. La ausencia de cambios evidentes de forma del fruto durante el crecimiento y el desarrollo de granadas 'Helow' y 'Qusum' indica la adopción de una forma característica del fruto puede que no sea un buen indicador de madurez para la gestión de la cosecha. De este modo, el tamaño y la forma de los frutos no pueden ser los únicos caracteres a tener en cuenta para decidir la fecha de cosecha, y deberían considerarse otras características físico-químicas del fruto para evaluar el punto de cosecha que permitiera garantizar un ingreso óptimo a los cultivadores.

Omán / Punica granatum / frutas / indice de crecimiento / etapas de desarrollo / cosecha / indicadores de desarrollo 